einstein

Official Publication of the Instituto Israelita

de Ensino e Pesquisa Albert Einstein

ISSN: 1679-4508 | e-ISSN: 2317-6385
How to cite this article:

Girolineto BM, Oliveira AM, Gonçalves AM, Campos MS, Pereira LR. INSAF-HAS: a tool to select patients with hypertension for pharmaceutical care. einstein (São Paulo). 2020:18:eA04858. http://dx.doi.org/10.31744/ einstein journal/2020A04858

Corresponding author:

Alan Maicon de Oliveira

Avenida do Café, s/n - Vila Monte Alegre

Zip code: 14040-903 - Ribeirão Preto, SP, Brazil

Phone: (55 16) 3315-0254

E-mail: alanoliveira@usp.br

Received on:

Nov 21, 2018

Accepted on:

July 2, 2019

Conflict of interest:

none.

Copyright 2019

(c) BY

This content is licensed

under a Creative Commons

Attribution 4.0 International License.
ORIGINAL ARTICLE

\section{INSAF-HAS: a tool to select patients with hypertension for pharmaceutical care}

\author{
INSAF-HAS: ferramenta para seleção de pacientes com \\ hipertensão arterial sistêmica e inserção em serviços \\ de cuidado farmacêutico
}

Beatriz Maria Pereira Girolineto ${ }^{1}$, Alan Maicon de Oliveira², Ana Maria Rosa Freato Gonçalves², Marília Silveira de Almeida Campos², Leonardo Régis Leira Pereira²

${ }^{1}$ Universidade Federal do Piauí, Teresina, PI, Brazil.

2 Faculdade de Ciências Farmacêuticas de Ribeirão Preto, Universidade de São Paulo, Ribeirão Preto, SP, Brazil.

DOI: 10.31744/einstein_journal/2020A04858

\section{ABSTRACT}

Objective: To develop and validate the content of a tool aimed to select patients with hypertension for pharmaceutical care, based on identification of individuals in greater need of attention. Methods: The tool was developed and assessed for face and content validity, which was carried out in three stages. Phase I consisted of comprehensive literature review, which prompted the development of the first version of the tool. Phase II consisted of validation by an expert panel. Phase III consisted of a pilot study with hypertensive patients and preparation of the final version of the instrument. Results: Literature review yielded 30 studies, out of which 13 factors associated with hypertension and cardiovascular disease control and complications were selected. Once the initial version of the tool named INSAF-HAS was obtained, four expert meetings were held, each leading to instrument improvement until a final consensus was reached. In the pilot study, INSAF-HAS was applied to 30 patients with a diagnosis of hypertension for applicability pretest; adjustments were made and the final version of INSAFHAS obtained. Conclusion: The INSAF-HAS tool developed in this study has face and content validity, and may contribute to the selection of patients with hypertension in greater need of pharmaceutical care services.

Keywords: Pharmaceutical services; Hypertension; Antihypertensive agents; Surveys and questionnaires; Triage; Professional-patient relations; Quality management; Patient selection

\section{RESUMO}

Objetivo: Desenvolver e realizar a validação de conteúdo de uma ferramenta para seleção de pacientes com hipertensão arterial sistêmica a serem atendidos em serviços de cuidado farmacêutico, com base na identificação daqueles com maior necessidade dessa assistência. Métodos: 0 instrumento foi desenvolvido e avaliado por validação de face e conteúdo, subdividida em três fases. A fase I abordou ampla revisão bibliográfica, que originou a versão inicial da ferramenta. Na fase II, realizou-se a validação com a análise de um painel de experts. A fase III foi composta por estudo piloto realizado com pacientes com hipertensão, tendo sido definida a versão final do instrumento. Resultados: A partir da revisão bibliográfica, 30 estudos foram consultados, e foram selecionados 13 fatores associados ao controle e à ocorrência de complicações, relacionados à hipertensão arterial sistêmica e a doenças cardiovasculares. Por conseguinte, mediante a versão inicial da ferramenta intitulada INSAF-HAS, realizaram-se quatro reuniões com especialistas, para obtenção de consenso final. A cada encontro, o instrumento foi aprimorado. No estudo piloto, 30 pacientes com diagnóstico de hipertensão arterial sistêmica foram abordados para o pré-teste de avaliação da aplicabilidade e, após as adequações, obtevese a versão final do INSAF-HAS. Conclusão: A ferramenta elaborada INSAF-HAS apresenta 
validade de face e conteúdo. Ela deve contribuir para a seleção de pacientes portadores de hipertensão arterial sistêmica e com maior necessidade de participação em serviços de cuidado farmacêutico.

Descritores: Assistência farmacêutica; Hipertensão; Anti-hipertensivos; Inquéritos e questionários; Triagem; Relações profissional-paciente; Gestão de qualidade; Seleção de pacientes

\section{INTRODUCTION}

Hypertension (HTN) is a multifactorial clinical condition characterized by sustained elevation of blood pressure levels, with potential injury to target organs. ${ }^{(1)}$ The 2010 prevalence of hypertension in medium- and low-income countries, such as Brazil, and in highincome countries amounted to $31.5 \%$ (30.2\% to $32.9 \%$ ) and $28.5 \%$ (27.3\% to $29.7 \%$ ), respectively. ${ }^{(2)}$ According to research data, the prevalence of HTN in the Brazilian population ranges from $22.3 \%$ to $64.1 \%$. . $^{(3-9)}$

Uncontrolled HTN may trigger the development and/or aggravation of cardiovascular diseases, such as stroke, acute myocardial infarction (MI) and heart failure. ${ }^{(10)}$ Therefore, HTN treatment is vital to prevent these events. ${ }^{(10)}$

Pharmacotherapy plays an important role in HTN management; however, evidence suggests that blood pressure control among hypertensive patients is poor, with only $15.5 \%$ to $63 \%$ achieving that goal. ${ }^{(11-15)}$ Several factors may contribute to pharmacotherapy non-effectiveness, such as medication errors, inadequate prescription and lack of adherence treatment, among others.

Effective contribution of clinical pharmacists to improvement of patient quality of life, identification and resolution of pharmacotherapeutic problems, control of clinical parameters and reduction of costs associated with chronic diseases, such as diabetes mellitus (DM), dyslipidemia and HTN has been consistently demonstrated in several studies. ${ }^{(16-21)}$ Hence, integration of pharmaceutical care ${ }^{(22)}$ with health care provision is an effective strategy, with potential clinical, humanistic and economic impacts. ${ }^{(23-30)}$

In Brazil, pharmacists are often deeply involved in management activities, making it difficult to provide clinical advice for patients requiring personalized attention. ${ }^{(31-33)}$ Triage tools critically related to successful clinical pharmacy practice are needed to expand and direct this approach to patients with greater pharmacotherapeutic needs. ${ }^{(34)}$

\section{OBJECTIVE}

To develop and validate a tool aimed to select patients suffering from hypertension with greater therapeutic needs for inclusion in pharmaceutical care services.

\section{METHODS}

This study involved three phases of development and validation of a screening tool designed for HTN patients (INSAF-HAS; Figure 1). Phase I consisted of a literature review for preparation of the initial version of the tool. In phase II, the instrument was evaluated by an expert panel. Phase III consisted of a pilot to test respondents' understanding of questions and questionnaire practicality in order to define the final version. This study was approved by the Research Ethics Committee of Faculdade de Ciências Farmacêuticas de Ribeirão Preto, Universidade de São Paulo, protocol no. 67/2011.

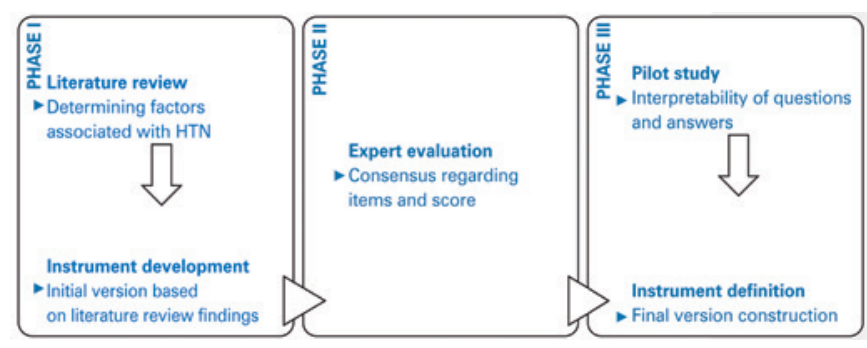

HTN: hypertension.

Figure 1. Tool development process based on face and content validity

\section{Phase I: literature review and instrument development}

A literature review was carried out to identify factors associated with HTN. PubMed ${ }^{\circledR}$ database was searched using Medical Subject Headings (MeSH) terms related to pharmaceutical care (pharmaceutical services), HTN (hypertension and risk factors) and adherence to medical therapy (medication adherence and patient compliance).

Following article selection, references related to the topic listed in the first studies were also examined. The initial version of INSAF-HAS was then created, based on critical reading of selected documents.

\section{Phase II: expert panel}

The first version was evaluated by five expert pharmacists with a solid background (teaching, research and professional experience) in pharmaceutical care provision and HTN, all of them $\mathrm{PhD}$ students in this 
field. ${ }^{(35)}$ Expert panels consisted of in-person meetings for analysis of individual item pertinence and clarity. Experts could also refine concepts and suggest inclusion of elements potentially associated or not associated with HTN control.

\section{Phase III: pilot study and definition of the official instrument}

A pilot study was then carried out for identification of potential difficulties associated with respondents' understanding of questions and questionnaire practicality and applicability. This phase was conducted at a primary care unit located in the city of Ribeirão Preto (SP), Brazil. In order to minimize potential questionnaire biases, a duly trained pharmacist applied the instrument (face-to-face interviews) to a convenience sample of patients diagnosed with HTN aged 18 years or older, and using at least one anti-hypertensive drug. Volunteers were recruited at the pharmacy of the aforementioned primary care unit while getting their prescriptions.

Difficulties noted were discussed and items rephrased or modified according to expert consensus view. Pilot study completion was achieved when 11 consecutive participants reported and revealed proper understanding of instrument items.

The final version was then prepared and item weights assigned according to experts' opinion to yield a final score.

\section{RESULTS}

Phase I

Thirty studies (including guidelines) were selected; these were analyzed for definition of indicators to be included in the instrument. Following critical review, factors reported in literature as being associated with blood pressure (BP) control, HTN- and cardiovascular disease-related complications and aggravations, adherence to pharmacological treatment and occurrence of pharmacotherapy-related problems were selected (Table 1). Nonetheless, some controversial factors, such as stress, depression and coffee intake were not included.

The initial version of INSAF-HAS (Appendix 1) was then obtained. Over the course of assessments, factors potentially affecting practical application of the instrument and response reliability (obesity, salt intake, previous renal failure or hypertensive retinopathy) were also excluded.

\section{Phase II}

Four expert meetings were required for analysis and discussion until a final consensus was reached (Figure 2). Item clarity and relevance of each indicator were assessed during such meetings; individual item weights and final scores were then attributed accordingly. Each meeting led to modifications of the tool (versions 2 to 5) (Appendix 1).

Different weights were attributed to different factors according to their respective significance for clinical progression of HTN. A score ranging from 9 to 200 (Table 2) was then defined; the lower the score, the lower the need of pharmaceutical care.

Table 1. Determining factors in clinical outcomes related to progression of hypertension

\begin{tabular}{|c|c|}
\hline Factors & Studies \\
\hline \multirow[t]{3}{*}{ Age and sex } & Sociedade Brasileira de Cardiologia ${ }^{(36)}$ \\
\hline & Gueyffier et al. ${ }^{(37)}$ \\
\hline & Takahashi et al. ${ }^{(38)}$ \\
\hline Level of education & Vasconcelos et al..$^{(39)}$ \\
\hline \multirow[t]{3}{*}{ Regular physical exercise practice } & Sociedade Brasileira de Cardiologia ${ }^{(36)}$ \\
\hline & O’Donnell et al..$^{(40)}$ \\
\hline & Pescatello et al..$^{(41)}$ \\
\hline \multirow[t]{5}{*}{ Smoking } & Sociedade Brasileira de Cardiologia ${ }^{(36)}$ \\
\hline & Gueyffier et al. ${ }^{\mid 37]}$ \\
\hline & O’Donnell et al..$^{(40)}$ \\
\hline & Ridker et al..$^{(42)}$ \\
\hline & Rempher ${ }^{(43)}$ \\
\hline \multirow[t]{3}{*}{ Alcohol abuse } & Sociedade Brasileira de Cardiologia ${ }^{(36)}$ \\
\hline & Parekh et al. ${ }^{(44)}$ \\
\hline & Taylor et al. ${ }^{(45)}$ \\
\hline \multirow[t]{3}{*}{ Adherence to pharmacotherapy } & Vasconcelos et al. ${ }^{(39)}$ \\
\hline & Bunker et al. ${ }^{\mid 46)}$ \\
\hline & Balkrishnan ${ }^{[4\rangle}$ \\
\hline Access to drugs & $\begin{array}{l}\text { Vasconcelos et al. }{ }^{(39)} \\
\text { Balkrishnan }{ }^{|47\rangle}\end{array}$ \\
\hline Need of care provider & Vasconcelos et al..$^{(39)}$ \\
\hline \multirow[t]{3}{*}{ Use of drugs potentially leading to BP elevation } & Sociedade Brasileira de Cardiologia ${ }^{(36)}$ \\
\hline & Amer et al..48) \\
\hline & Snowden et al.(49) \\
\hline \multirow[t]{5}{*}{ Comorbidities: diabetes mellitus and dyslipidemia } & Gueyffier et al. ${ }^{(37)}$ \\
\hline & Ridker et al. ${ }^{(42)}$ \\
\hline & Piegas et al. ${ }^{(50)}$ \\
\hline & Cubeddu et al. ${ }^{(51)}$ \\
\hline & Reaven. ${ }^{(52)}$ \\
\hline \multirow[t]{2}{*}{ Previous aggravations: acute $\mathrm{Ml}$ and stroke } & Gueyffier et al. ${ }^{(37)}$ \\
\hline & Schmieder ${ }^{(53)}$ \\
\hline \multirow{2}{*}{$\begin{array}{l}\text { Family history: HTN, dyslipidemia, diabetes } \\
\text { mellitus, acute Ml and stroke }\end{array}$} & Harrison et al. ${ }^{(54)}$ \\
\hline & Kennedy et al. ${ }^{(55)}$ \\
\hline
\end{tabular}

BP: blood pressure; MI: myocardial infarction; HTN: hypertension. 


\section{Phase III}

After the expert panel reached a final consensus about INSAF-HAS, a pre-test procedure was put in place to test the applicability of the instrument (i.e., to check whether respondents were actually able to understand questions). Thirty patients diagnosed with HTN were approached while getting their prescriptions at the primary care unit, until a total of 11 consecutive participants revealed proper understanding of all instrument items.

The questionnaire was further modified during this period (Table 3). Some questions were rephrased for improved interpretability; these formed the final INSAF-HAS version (Appendix 2).

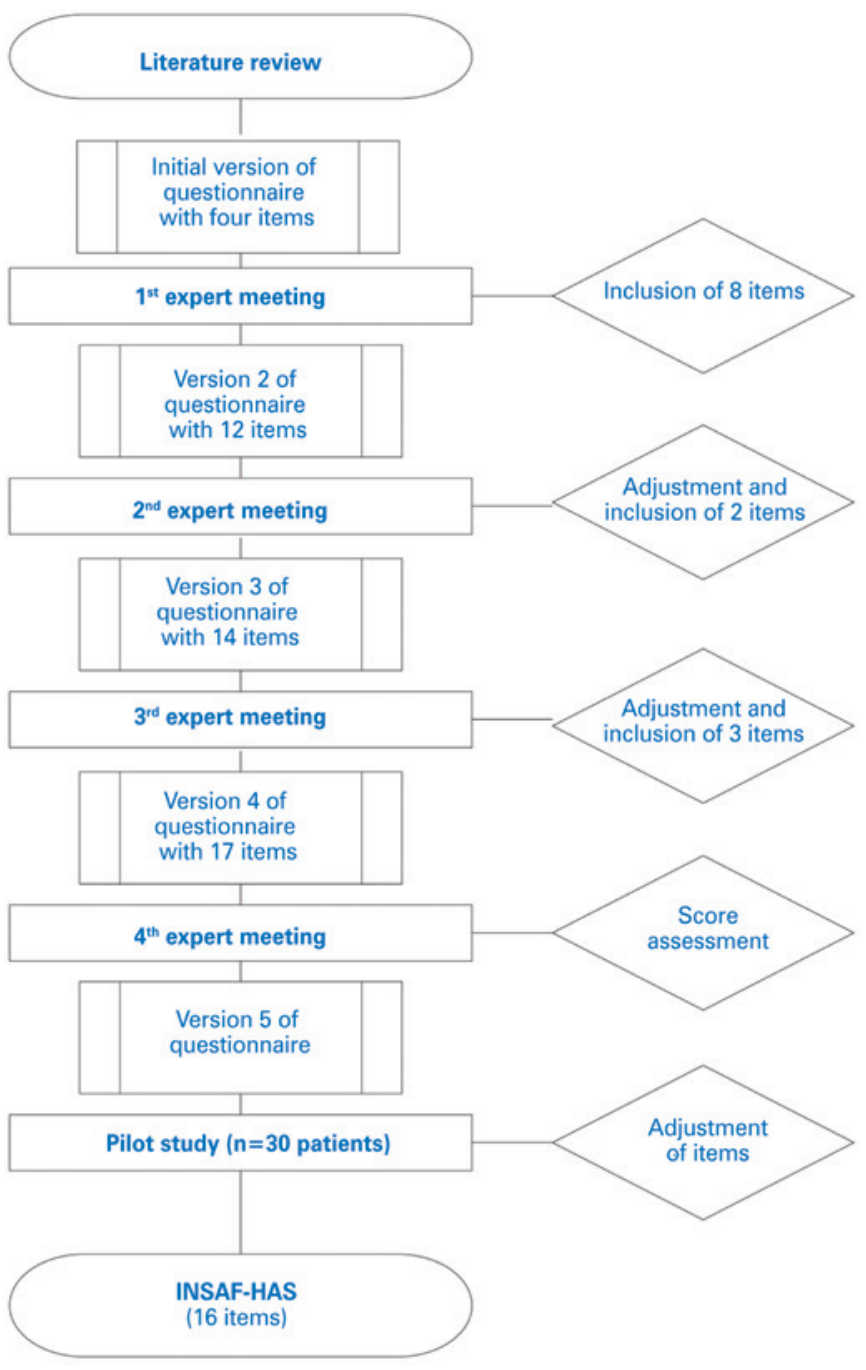

Figure 2. Flowchart displaying INSAF-HAS development process
Table 2. Minimum and maximum scores per INSAF-HAS item

\begin{tabular}{lcc}
\hline Questionnaire item & Minimum score & Maximum score \\
\hline 1 & 1 & 9 \\
\hline 2 & 0 & 8 \\
3 & 0 & 6 \\
\hline 4 & 0 & 5 \\
\hline 5 & 0 & 13 \\
\hline 6 & 0 & 9 \\
\hline 7 & 0 & 7 \\
\hline 8 & 0 & 11 \\
\hline 9 & 0 & 9 \\
\hline 10 & 8 & 23 \\
\hline 11 & 0 & 7 \\
\hline 12 & 0 & 16 \\
\hline 13 & 0 & 7 \\
\hline 14 & 0 & 16 \\
\hline 15 & 0 & 52 \\
\hline 16 & 0 & 2 \\
\hline Total & 9 & $\mathbf{2 0 0}$ \\
\hline & & \\
\hline
\end{tabular}

\section{DISCUSSION}

This study led to the development of a dedicated tool for analysis of factors associated with therapeutic and clinical aspects of HTN patients. Scientific evidences supporting screening tools for pharmaceutical care users are scarce and most studies approach different pharmacotherapeutic and clinical issues without a thorough, holistic assessment of patient profile. ${ }^{(56-60)}$ The fact that INSAF-HAS is not an inclusion or exclusion tool, but rather an instrument aimed to indicate individual priority of care, must be emphasized. Therefore, once successful care of selected patients is achieved, other patients meeting priority criteria may receive personalized pharmaceutical care.

Current health system demands emphasize the significance of clinical and public health education services provided by pharmacists. ${ }^{(61,62)}$ Still, motivation levers encouraging practical application of pharmaceutical knowledge are lacking, since the technicist profile prevails in several services (particularly in low- and middle-income countries). Moreover, there is outpatient health care overcrowding and ineffective management. These factors translate into lack of follow-up in patient-centered care. ${ }^{(62,63)}$ Aside from management and technical activities, tools aimed to optimize pharmaceutical care and promote 
Table 3. Modifications introduced in INSAF-HAS after completion of the pilot study

\begin{tabular}{|c|c|c|}
\hline Version 5 of INSAF-HAS & Reason for change & Final version of INSAF-HAS \\
\hline What is your level of education (how long did you study)? & Difficulties in speech interpretation & $\begin{array}{l}\text { What is your level of education (up to what grade did } \\
\text { you study)? }\end{array}$ \\
\hline Do you consume alcoholic drinks? & More objective question to assist interviewer & Do you consume alcoholic drinks? If yes, how much? \\
\hline Items 6 to 9 (comorbidities) & Order changed to facilitate prescription analysis & New order: items 11 to 14 \\
\hline Dot you have high blood pressure? & $\begin{array}{l}\text { Many patients were not able to describe their blood pressure control } \\
\text { status; this led to doubts, as all had been diagnosed with HTN }\end{array}$ & Exclusion \\
\hline $\begin{array}{l}\text { If answer to question } 10 \text { was "yes", how do you treat } \\
\text { your high blood pressure problem? }\end{array}$ & Changes due to exclusion of item 10 & How do you treat your high blood pressure problem? \\
\hline $\begin{array}{l}\text { Items } 12 \text { and } 13 \text { (HTN aggravations and family history, } \\
\text { respectively) }\end{array}$ & $\begin{array}{l}\text { Order changed to facilitate prescription analysis and improve patient } \\
\text { interview dynamics }\end{array}$ & New order: items 15 and 16 \\
\hline $\begin{array}{l}\text { Items } 14,15 \text { and } 16 \text { (adherence and access to } \\
\text { medication) }\end{array}$ & $\begin{array}{l}\text { Order changed to facilitate prescription analysis and improve patient } \\
\text { interview dynamics }\end{array}$ & New order: items 6, 7 and 9, respectively \\
\hline
\end{tabular}

inclusion of equitable access to pharmaceutical services in emerging initiatives, such as management of chronic non-communicable diseases and reduction in their mortality rates, are needed. ${ }^{(62)}$

This is a complex scenario involving organizational aspects of health care services and compatible professional expertise; up-front provision of pharmaceutical care to high risk patients may contribute to improved management of professional procedures and benefit patients in urgent need of critical care. ${ }^{(64)}$

The reality faced by pharmacists in charge of drug dispensing was taken into account in INSAF-HAS development, for these professionals will be able to use this tool in daily routine. Given the wide range of activities undertaken (care provision to patients, drug acquisition, inventory control and managementrelated activities), a simple, user-friendly questionnaire amenable to application within a limited time frame was developed. Complex, time-consuming procedures would hardly fit into the busy routine of pharmacists. INSAF-HAS comprises factors driving clinical progression of HTN that can be easily interrogated in the presence of affected patients (e.g., during drug dispensing) and constitutes an important aid in selection of patients for pharmaceutical care; it is also amenable to application by pharmacy technicians and assistants.

Among factors considered for instrument construction, elevated BP stands out as a significant risk factor for cardiovascular disease development and/ or aggravation. ${ }^{(36,37,42,65,66)}$ However, BP measurement may limit INSAF-HAS application by pharmacists and pharmacy teams due to the time required for completion of this procedure. Instead, experts discussed the possibility of including one question interrogation blood pressure control. Given blood pressure may not be measured frequently enough (i.e., patients may be not be aware of their BP levels), such a question might introduce a bias in patients selection. Therefore, questions interrogating blood pressure monitoring were not included. However, the tool is aimed at patients suffering from HTN, a risk factor for cardiovascular diseases per se. ${ }^{(40,67)}$ In an effort to improve instrument content and applicability, experts agreed upon the inclusion of one item interrogating BP treatment.

Elevated serum cholesterol (total and subfractions) is another important risk factor for cardiovascular disease. ${ }^{(42,50)}$ In Brazilian public laboratory services, this parameter is measured approximately every 6 months. Ideally, cholesterol levels should be measured via lab tests; however, given this may not be feasible due to time and financial constraints, values (potentially not up-to-date) would have to be extracted from medical records or new tests requested. Instead, questions interrogating dyslipidemia and respective treatment, backed by prescriptions, were thought to be a better alternative.

Diabetes mellitus, also a risk factor for cardiovascular disease, ${ }^{(37,42,51,52)}$ was assessed in a similar manner to dyslipidemia. Instead of resorting to laboratory (blood glucose or glycated hemoglobin) or capillary blood glucose test (finger pricking), DM was interrogated and confirmed via medical prescription of oral anti-diabetic drugs or insulin, ensuring INSAF-HAS accessibility and practicality.

Smoking, yet another risk factor for cardiovascular disease, ${ }^{(36,37,40,42,43)}$ was interrogated in INSAF-HAS via the direct question: "Have you ever smoked/do you currently smoke cigarettes?". The word "smoker" alone was avoided because it may be associated with illicit drug use (for instance, marijuana or crack), according 
to experts. "Cigarette smoking" was thought to be a more familiar term, particularly among individuals with lower levels of education, and was therefore selected for inclusion in INSAF-HAS.

Although some studies suggest beneficial effects of small doses of alcohol, red wine in particular, for atherosclerosis, ${ }^{(68,69)}$ alcohol consumption is associated with increased risk of HTN and should be avoided. ${ }^{(44,45)}$ According to the Brazilian Hypertension Guidelines [Diretrizes Brasileiras de Hipertensão], daily alcohol consumption should not exceed $30 \mathrm{~g}$ or $15 \mathrm{~g}$ (men and women, respectively). ${ }^{(36)}$ Therefore, these levels of alcohol consumption were interrogated in INSAF-HAS.

Other important factors included in the instrument were patient's age and sex. ${ }^{(36-38)}$ Male individuals are more prone to developing cardiovascular disease, particularly after the age of 55 years. In women, this risk increases after the onset of menopause (approximately at 50 years) and tends to rise even more after the age of 65 years.

Physical exercise practice reduces the risk of cardiovascular diseases, whereas sedentarism is a predisposing factor. ${ }^{(36,40,41)}$ Therefore, the tool proposed in this study interrogates physical exercise practice (physical activities lasting at least 30 minutes, three times per week, or 90 minutes/week).

Family history of HTN, dyslipidemia, DM and some conditions, such as acute MI and stroke in firstdegree relatives, are also thought to be risk factors for cardiovascular diseases. ${ }^{(54,55)}$ One question interrogating family history was therefore included in INSAF-HAS.

Previous HTN-related conditions, such as stroke, acute MI, renal failure and hypertensive retinopathy must also be accounted for. ${ }^{(37,53,70)}$ Given their significance, these factors were included in INSAF-HAS; however, during the pre-test phase, respondents were often unable to provide reliable information regarding such aggravations.

Some patients were not able to understand the meaning of the term "renal failure". The term "kidney problem" was then selected, but lack of understanding persisted. When asked whether they "had kidney problems", patients were not able to differentiate between renal failure and other diseases affecting the urinary system, such as cystitis or nephrolithiasis. As use of medical record data was not an option, and reliable confirmation of renal failure diagnosis could not be obtained via self-reporting, this cardiovascular disease risk factor was excluded from the final version of the instrument.

Likewise, most patients were unable to grasp the meaning of "hypertensive retinopathy" in the pre-test phase. The term "vision problems" was then selected, but disorders associated with myopia and cataract induced patients to answer "yes", when interrogated about their "type of vision problem", precluding reliable data collection. Since the diagnosis could not be confirmed, this item was excluded from the final version of INSAF-HAS to mitigate potential errors.

Different from aforementioned aggravations, stroke and acute MI were easily self-reported. Patients had no doubts regarding the questions: "Have you ever had an infarction?" and "Have you ever had a cerebrovascular accident (CVA) or stroke?". Therefore, these items were retained in the instrument.

As regards pharmacotherapy, poor adherence to prescribed anti-hypertensive treatment is associated with poor BP control. ${ }^{(46)}$ Several aspects potentially interfering with compliance to plan of care, such as level of education (the lower the level of education, the greater the difficulty in properly understanding and following prescriptions), access to medications, ability to self-medicate and polypharmacy were accounted for. ${ }^{(39,47)}$ Individuals were also directly interrogated about adherence (i.e., whether they have ever forgotten/ chosen not to take medications as prescribed).

Controversial HTN-related factors, such as stress $^{(67,71)}$ depression $^{(67,72)}$ and coffee intake ${ }^{(36,73)}$ were not included. Obesity and salt intake ${ }^{(36,40,74-76)}$ were considered, but were also estimated to negatively interfere with tool application. In the case of obesity, time constraints associated with weight and height measurements required for body mass index calculation were the major reasons for exclusion. As regards salt intake, daily amounts consumed were deemed difficult to measure, as salt is not the only source of sodium in foods and people are often unable to quantify their daily salt consumption.

\section{Study limitations and strengths}

Assessment of some risk factors for cardiovascular disease was not consistent with tool objectives (accessibility and feasible application in routine pharmacy settings); these were therefore not included in the final version. However, INSAF-HAS is aimed to triage patients who will then receive pharmaceutical care; hence, excluded factors may still be assessed over the course of pharmaceutical care provision.

The fact that expert panel members selected to evaluate INSAF-HAS were all staff at the Faculdade de Ciências Farmacêuticas de Ribeirão Preto, Universidade de São Paulo, is a limitation of this study. 
Detailed description of item selection criteria, proper definition of the target population and conduction of a pilot study supported INSAF-HAS face and content validity. However, future studies assessing psychometric properties are needed.

In spite of these limitations, this initial study may provide significant contributions to the structuring of pharmaceutical care services. INSAF-HAS may be used to screen for patients in greater need of care, thereby optimizing professional care provision. This study may also encourage related debate and support pharmaceutical care practices in Brazil.

\section{CONCLUSION}

The INSAF-HAS tool created has face and content validity; it also lists and scores risk factors for hypertension among affected individuals. This tool may be used to screen patients in greater need of pharmaceutical care.

\section{ACKNOWLEDGMENTS}

To the Fundação de Amparo à Pesquisa do Estado de São Paulo (FAPESP), for the grant given to Beatriz Maria Pereira Girolineto (process: 11/00985-1; July 2011 to September 2014). The financing agency played no role in the design of the study, data collection and analysis, decision to publish or text writing. The authors are responsible for the opinions, assumptions and conclusions or recommendations expressed in this article, which do necessarily reflect the standpoint of FAPESP.

\section{AUTHORS' INFORMATION}

Girolineto BM: https://orcid.org/0000-0003-2887-4503

Oliveira AM: http://orcid.org/0000-0002-3880-0287

Gonçalves AM: http://orcid.org/0000-0002-9428-4539

Campos MS: http://orcid.org/0000-0003-2420-4641

Pereira LR: http://orcid.org/0000-0002-8609-1390

\section{REFERENCES}

1. Sociedade Brasileira de Cardiologia (SBC). $7^{a}$ Diretriz brasileira de hipertensão arterial [Internet]. Rio de Janeiro: SBC; 2016 [citado 2018 Dez 18]. Disponível em: http://publicacoes.cardiol.br/2014/diretrizes/2016/05 HIPERTENSAO ARTERIAL.pdf

2. Mills KT, Bundy JD, Kelly TN, Reed JE, Kearney PM, Reynolds K, et al. Global Disparities of Hypertension Prevalence and Control: A Systematic Analysis of Population-Based Studies From 90 Countries. Circulation. 2016;134(6):441-50.

3. Mengue SS, Bertoldi AD, Ramos LR, Farias MR, Oliveira MA, Tavares NL, et al. Access to and use of high blood pressure medications in Brazil. Rev Saude Publica. 2016;50(Suppl 2):8s.
4. Ala L, Gill G, Gurgel R, Cuevas L. Evidence for affluence-related hypertension in urban Brazil. J Hum Hypertens. 2004;18(11):775-9.

5. Cesarino CB, Cipullo JP, Martin JV, Ciorlia LA, Godoy MP, Cordeiro JA, et al. Prevalência e fatores sociodemográficos em hipertensos de São José do Rio Preto - SP. Arq Bras Cardiol. 2008;91(1):31-5.

6. Castro RA, Moncau JC, Marcopito LF. Prevalência de hipertensão arterial sistêmica na cidade de Formiga, MG. Arq Bras Cardiol. 2007;88(3):334-9.

7. Freitas OC, Carvalho FR, Neves JM, Veludo PK, Parreira RS, Gonçalves RM, et al. Prevalência da hipertensão arterial sistêmica na população urbana de Catanduva, SP. Arq Bras Cardiol. 2001;77:9-15.

8. Lyra R, Silva RS, Montenegro Junior RM, Matos MV, Cézar NJ, Fernandes V0, et al. High prevalence of arterial hypertension in a Brazilian Northeast population of low education and income level, and its association with obesity and metabolic syndrome. Rev Assoc Med Bras (1992). 2012;58(2):209-14.

9. Rosário TM, Scala LC, França GV, Pereira MR, Jardim PC. Prevalência, controle e tratamento da hipertensão arterial sistêmica em Nobres - MT. Arq Bras Cardiol. 2009;93(6):672-8.

10. Stout KK, Daniels CJ, Aboulhosn JA, Bozkurt B, Broberg CS, Colman JM, et al. 2018 AHA/ACC Guideline for the Management of Adults With Congenital Heart Disease: Executive Summary: A Report of the American College of Cardiology/American Heart Association Task Force on Clinical Practice Guidelines. J Am Coll Cardiol. 2019;73(12):1494-1563. Erratum in: J Am Coll Cardiol. 2019;73(18):2361.

11. Banegas JR, Rodríguez-Artalejo F, de la Cruz Troca JJ, Guallar-Castillón P, del Rey Calero J. Blood pressure in Spain: distribution, awareness, control, and benefits of a reduction in average pressure. Hypertension. 1998;32(6):9981002.

12. Colósimo FC, Silva SS, Toma GA, Pierin AM. Nursing actions increases the control of hypertensive patients and reduces white-coat effect. Rev Esc Enferm USP. 2012;46(Esp):10-5.

13. Hajjar I, Kotchen TA. Trends in prevalence, awareness, treatment, and control of hypertension in the United States, 1988-2000. JAMA. 2003;290(2):199-206.

14. Roger VL, Go AS, Lloyd-Jones DM, Benjamin EJ, Berry JD, Borden WB, et al.; American Heart Association Statistics Committee and Stroke Statistics Subcommittee. Heart disease and stroke statistics-2012 update: a report from the American Heart Association. Circulation. 2012;125(1):e2-220.

15. Yiannakopoulou EC, Papadopulos JS, Cokkinos DV, Mountokalakis TD. Adherence to antihypertensive treatment: a critical factor for blood pressure control. Eur J Cardiovasc Prev Rehabil. 2005;12(3):243-9.

16. Erickson SR, Slaughter R, Halapy H. Pharmacists' ability to influence outcomes of hypertension therapy. Pharmacotherapy. 1997;17(1):140-7.

17. Lee WW, Yi PT, Kong KW, Chan PK, Kwok FL. Impact of pharmacy outreach services on blood pressure management in the elderly community of Hong Kong. Geriatr Gerontol Int. 2013;13(1):175-81.

18. Magid DJ, Olson KL, Billups SJ, Wagner NM, Lyons EE, Kroner BA. A pharmacist-led, American Heart Association Heart360 Web-enabled home blood pressure monitoring program. Circ Cardiovasc Qual Outcomes. 2013; 6(2):157-63.

19. Neto PR, Marusic S, de Lyra Júnior DP, Pilger D, Cruciol-Souza JM, Gaeti WP, et al. Effect of a 36-month pharmaceutical care program on the coronary heart disease risk in elderly diabetic and hypertensive patients. J Pharm Pharm Sci. 2011;14(2):249-63.

20. Parker $\mathrm{CP}$, Cunningham $\mathrm{CL}$, Carter BL, Vander Weg MW, Richardson KK, Rosenthal GE. A mixed-method approach to evaluate a pharmacist intervention for veterans with hypertension. J Clin Hypertens (Greenwich) 2014;16(2):133-40.

21. Zillich AJ, Sutherland JM, Kumbera PA, Carter BL. Hypertension outcomes through blood pressure monitoring and evaluation by pharmacists (HOME study). J Gen Intern Med. 2005;20(12):1091-6.

22. Brasil. Ministério da Saúde. Secretaria de Ciência Tecnologia e Insumos Estratégicos. Departamento de Assistência Farmacêutica e Insumos Estratégicos. Cuidado farmacêutico na atenção básica. Brasília (DF): Ministério da Saúde; 2014. [Caderno 1: cuidado farmacêutico na atenção básica]. 
23. Aguiar PM, Balisa-Rocha BJ, Brito GC, Lyra DP Jr. Pharmaceutical care program for elderly patients with uncontrolled hypertension. J Am Pharm Assoc (2003). 2012;52(4):515-8.

24. Carter BL, Rogers M, Daly J, Zheng S, James PA. The potency of team-based care interventions for hypertension: a meta-analysis. Arch Intern Med. 2009; 169(19):1748-55. Review.

25. Obreli-Neto PR, Marusic S, Guidoni CM, Baldoni AO, Renovato RD, Pilger D, et al. Economic evaluation of a pharmaceutical care program for elderly diabetic and hypertensive patients in primary health care: a 36-month randomized controlled clinical trial. J Manag Care Spec Pharm. 2015;21(1):66-75.

26. Mourão $A 0$, Ferreira WR, Martins $M A$, Reis $A M$, Carrillo $M R$, Guimarães $A G$, et al. Pharmaceutical care program for type 2 diabetes patients in Brazil: a randomised controlled trial. Int J Clin Pharm. 2013;35(1):79-86.

27. Viswanathan M, Kahwati LC, Golin CE, Blalock SJ, Coker-Schwimmer E, Posey R, et al. Medication therapy management interventions in outpatient settings: a systematic review and meta-analysis. JAMA Intern Med. 2015; 175(1):76-87.

28. Hirsch JD, Steers N, Adler DS, Kuo GM, Morello CM, Lang M, et al. Primary care-based, pharmacist-physician collaborative medication-therapy management of hypertension: a randomized, pragmatic trial. Clin Ther. 2014;36(9):1244-54.

29. Bunting BA, Smith BH, Sutherland SE. The Asheville Project: clinical and economic outcomes of a community-based long-term medication therapy management program for hypertension and dyslipidemia. J Am Pharm Assoc (2003). 2008;48(1):23-31.

30. Planas LG, Crosby KM, Mitchell KD, Farmer KC. Evaluation of a hypertension medication therapy management program in patients with diabetes. J Am Pharm Assoc (2003). 2009;49(2):164-70.

31. Leite SN, Nascimento JM Jr, Costa LH, Barbano DA. I Fórum Nacional de Educação Farmacêutica: o farmacêutico que o Brasil necessita. Interface Comunicacao Saude Educ. 2008;12(25):461-2.

32. Dewulf NL, dos Santos V, Leira Pereira LR, Troncon LE. The invisible pharmacist. Am J Pharm Educ. 2009;73(4):74.

33. Oliveira AB, Oyakawa CN, Miguel MD, Zanin SM, Montrucchio DP. Obstáculos da atenção farmacêutica no Brasil. Rev Bras Cienc Farm. 2005;41 (4):409-13.

34. Blackburn DF, Yakiwchuk EM, Jorgenson DJ, Mansell KD. Proposing a redefinition of pharmaceutical care. Ann Pharmacother. 2012;46(3):447-9.

35. Terwee CB, Bot SD, de Boer MR, van der Windt DA, Knol DL, Dekker J, et al. Quality criteria were proposed for measurement properties of health status questionnaires. J Clin Epidemiol. 2007;60(1):34-42.

36. Sociedade Brasileira de Cardiologia. Sociedade Brasileira de Hipertensão. Sociedade Brasileira de Nefrologia. VI Diretrizes Brasileiras de Hipertensão. Arq Bras Cardiol. 2010;95(1 supl.1):1-51

37. Gueyffier F, Boissel JP, Pocock S, Boutitie F, Coope J, Cutler J, et al. Identification of risk factors in hypertensive patients: contribution of randomized controlled trials through an individual patient database. Circulation. 1999;100(18):e88-94.

38. Takahashi K, Miura S, Mori-Abe A, Kawagoe J, Takata K, Ohmichi M, et al. Impact of menopause on the augmentation of arterial stiffness with aging. Gynecol Obstet Invest. 2005;60(3):162-6.

39. Vasconcelos FF, Victor JF, Moreira TM, Araújo TL. Utilização medicamentosa por idosos de uma Unidade Básica de Saúde da Família de Fortaleza - CE. Acta Paul Enferm. 2005;18(2):178-83.

40. O'Donnell MJ, Xavier D, Liu L, Zhang H, Chin SL, Rao-Melacini P, Rangarajan S, Islam S, Pais P, McQueen MJ, Mondo C, Damasceno A, Lopez-Jaramillo P, Hankey GJ, Dans AL, Yusoff K, Truelsen T, Diener HC, Sacco RL, Ryglewicz D, Czlonkowska A, Weimar C, Wang X, Yusuf S; INTERSTROKE investigators. Risk factors for ischaemic and intracerebral haemorrhagic stroke in 22 countries (the INTERSTROKE study): a case-control study. Lancet. 2010;376(9735):112-23

41. Pescatello LS, Franklin BA, Fagard R, Farquhar WB, Kelley GA, Ray CA; American College of Sports Medicine. American College of Sports Medicine position stand. Exercise and hypertension. Med Sci Sports Exerc. 2004;36(3):533-53. Review.
42. Ridker PM, Antman EM. Pathogenesis and pathology of coronary heart disease syndromes. J Thromb Thrombolysis. 1999;8(3):167-89. Review.

43. Rempher KJ. Cardiovascular sequelae of tobacco smoking. Crit Care Nurs Clin North Am. 2006;18(1):13-20. Review.

44. Parekh RS, Klag MJ. Alcohol: role in the development of hypertension and end-stage renal disease. Curr Opin Nephrol Hypertens. 2001;10(3):385-90.

45. Taylor B, Irving HM, Baliunas D, Roerecke M, Patra J, Mohapatra S, et al. Alcohol and hypertension: gender differences in dose-response relationships determined through systematic review and meta-analysis. Addiction. 2009;104(12):1981-90. Review.

46. Bunker J, Callister W, Chang CL, Sever PS. How common is true resistant hypertension? J Hum Hypertens. 2011;25(2):137-40.

47. Balkrishnan R. Predictors of medication adherence in the elderly. Clin Ther. 1998;20(4):764-71. Review.

48. Amer M, Bead VR, Bathon J, Blumenthal RS, Edwards DN. Use of nonsteroidal anti-inflammatory drugs in patients with cardiovascular disease: a cautionary tale. Cardiol Rev. 2010;18(4):204-12. Review.

49. Snowden S, Nelson R. The effects of nonsteroidal anti-inflammatory drugs on blood pressure in hypertensive patients. Cardiol Rev. 2011;19(4):184-91. Review.

50. Piegas LS, Avezum A, Pereira JC, Neto JM, Hoepfner C, Farran JA, Ramos RF, Timerman A, Esteves JP; AFIRMAR Study Investigators. Risk factors for myocardial infarction in Brazil. Am Heart J. 2003;146(2):331-8.

51. Cubeddu $L X$, Hoffmann IS. Insulin resistance and upper-normal glucose levels in hypertension: a review. J Hum Hypertens. 2002;16(S1 Suppl 1):S52-5.

52. Reaven GM. Relationships among insulin resistance, type 2 diabetes, essential hypertension, and cardiovascular disease: similarities and differences. J Clin Hypertens (Greenwich). 2011;13(4):238-43. Review.

53. Schmieder RE. End organ damage in hypertension. Dtsch Arztebl Int. 2010; 107(49):866-73. Review.

54. Harrison TA, Hindorff LA, Kim H, Wines RC, Bowen DJ, McGrath BB, et al Family history of diabetes as a potential public health tool. Am J Prev Med. 2003;24(2):152-9. Review.

55. Kennedy RE, Howard G, Go RC, Rothwell PM, Tiwari HK, Feng R, et al. Association between family risk of stroke and myocardial infarction with prevalent risk factors and coexisting diseases. Stroke. 2012;43(4):974-9.

56. Blalock SJ, Patel RA. Drug therapy concerns questionnaire: initial development and refinement. J Am Pharm Assoc (2003). 2005;45(2):160-9.

57. Langford BJ, Jorgenson D, Kwan D, Papoushek C. Implementation of a selfadministered questionnaire to identify patients at risk for medication-related problems in a family health center. Pharmacotherapy. 2006;26(2):260-8.

58. Rovers J, Hagel H. Self-assessment tool for screening patients at risk for drug therapy problems. J Am Pharm Assoc (2003). 2012;52(5):646-52.

59. Snyder ME, Frail CK, Jaynes H, Pater KS, Zillich AJ. Predictors of medication-related problems among medicaid patients participating in a pharmacist-provided telephonic medication therapy management program. Pharmacotherapy. 2014;34(10):1022-32.

60. Snyder ME, Pater KS, Frail CK, Hudmon KS, Doebbeling BN, Smith RB. Utility of a brief screening tool for medication-related problems. Res Social Adm Pharm. 2015;11(2):253-64.

61. American Public Health Association (APHA). The role of the pharmacist in public health [Internet]. Washington, DC: APHA; 2006 [cited 2019 June 12]. Available from: https://www.apha.org/policies-and-advocacy/public-healthpolicy-statements/policy-database/2014/07/07/13/05/the-role-of-thepharmacist-in-public-health

62. Law MG, Maposa P, Steeb DR, Duncan G. Addressing the global need for public health clinical pharmacists through student pharmacist education: a focus on developing nations. Int J Clin Pharm. 2017;39(6):1141-4.

63. Anderson S. The state of the world's pharmacy: a portrait of the pharmacy profession. J Interprof Care. 2002;16(4):391-404.

64. Morillo-Verdugo R, Martínez-Sesmero JM, Lázaro-López A, Sánchez-Rubio J, Navarro-Aznárez H, DeMiguel-Cascón M. Development of a risk stratification model for pharmaceutical care in HIV patients. Farm Hosp. 2017;41 (3):346-56. 
65. Collins R, Peto R, MacMahon S, Hebert P, Fiebach NH, Eberlein KA, et al. Blood pressure, stroke, and coronary heart disease. Part 2, Short-term reductions in blood pressure: overview of randomised drug trials in their epidemiological context. Lancet. 1990;335(8693):827-38.

66. MacMahon S, Peto R, Cutler J, Collins R, Sorlie P, Neaton J, et al. Blood pressure, stroke, and coronary heart disease. Part 1, Prolonged differences in blood pressure: prospective observational studies corrected for the regression dilution bias. Lancet. 1990;335(8692):765-74.

67. Lanas F, Avezum A, Bautista LE, Diaz R, Luna M, Islam S, Yusuf S; INTERHEART Investigators in Latin America. Risk factors for acute myocardial infarction in Latin America: the INTERHEART Latin American study. Circulation. 2007; 115(9):1067-74.

68. Avellone G, Di Garbo V, Campisi D, De Simone R, Raneli G, Scaglione R, et al. Effects of moderate Sicilian red wine consumption on inflammatory biomarkers of atherosclerosis. Eur J Clin Nutr. 2006;60(1):41-7.

69. Naissides M, Mamo JC, James AP, Pal S. The effect of chronic consumption of red wine on cardiovascular disease risk factors in postmenopausal women. Atherosclerosis. 2006;185(2):438-45.
70. Alebiosu CO. An update on 'progression promoters' in renal diseases. J Natl Med Assoc. 2003;95(1):30-42.

71. Scherr C, Ribeiro JP. Gênero, idade, nível social e fatores de risco cardiovascular: considerações sobre a realidade brasileira. Arq Bras Cardiol. 2009;93(3):e54-6.

72. Yan LL, Liu K, Matthews KA, Daviglus ML, Ferguson TF, Kiefe Cl. Psychosocial factors and risk of hypertension: the coronary artery risk development in young adults (cardia) study. JAMA. 2003;290(16):2138-48.

73. Zhang Z, Hu G, Caballero B, Appel L, Chen L. Habitual coffee consumption and risk of hypertension: a systematic review and meta-analysis of prospective observational studies. Am J Clin Nutr. 2011;93(6):1212-9.

74. Chrysant GS. High salt intake and cardiovascular disease: is there a connection? Nutrition. 2000;16(7-8):662-4.

75. Poirier P, Giles TD, Bray GA, Hong Y, Stern JS, Pi-Sunyer FX, et al. Obesity and cardiovascular disease: pathophysiology, evaluation, and effect of weight loss. Arterioscler Thromb Vasc Biol. 2006;26(5):968-76.

76. Ritz E. Salt and hypertension. Nephrology (Carlton). 2010;15(Suppl 2):49-52. 